\title{
Effectiveness of Intraoperative Cell Salvage Combined with a Modified Leucocyte Depletion Filter in Metastatic Spine Tumour Surgery
}

\author{
Ya-nan Zong \\ Peking University Third Hospital \\ Chuan-ya Xu \\ Peking University Third Hospital \\ Yue-qing Gong \\ Peking University Third Hospital \\ Xiao-qing Zhang \\ Peking University Third Hospital \\ Hong Zeng \\ Peking University Third Hospital \\ Chang Liu \\ Peking University Third Hospital \\ Bin Zhang \\ Peking University Third Hospital \\ Li-xiang Xue \\ Peking University Third Hospital \\ Xiang-yang Guo \\ Peking University Third Hospital

\section{Feng Wei} \\ Peking University Third Hospital \\ Yi Li ( $\square$ liyi@bjmu.edu.cn ) \\ Peking University Third Hospital
}

\section{Research Article}

Keywords: Intraoperative cell salvage, Modified leucocyte depletion filter, Regular leucocyte depletion filter, Metastatic spine tumour surgery

Posted Date: January 7th, 2022

DOl: https://doi.org/10.21203/rs.3.rs-1169327/v1

License: () (1) This work is licensed under a Creative Commons Attribution 4.0 International License. Read Full License 


\section{Abstract \\ Background}

To compare the effectiveness of intraoperative cell salvage (IOCS) combined with a modified leucocyte depletion filter (MLDF) with IOCS combined with a regular leucocyte depletion filter (RLDF) in eliminating tumour cells from blood salvage during metastatic spine tumour surgery (MSTS).

\section{Methods}

Patients with a known primary epithelial tumour who underwent MSTS were recruited for this study. Blood samples were collected in 5 stages: from the patients' vein before anaesthesia induction (S1), from the operative field during tumour manipulation (S2), and from the operative blood after IOCS processing (S3) and after IOCS+RLDF (S4) and IOCS+MLDF (S5) processing. The polyploids of tumour cells in the blood samples were collected and counted with immunomagnetic separation enrichment and fluorescence in situ hybridization.

\section{Results}

We recruited 20 patients. Tumour cells were detected in 14 patients (70\%) in S1, 16 patients (80\%) in S2, 13 patients (65\%) in S3, and 12 patients $(60 \%)$ in S4. MLDF was added in 8 patients. Tumour cells were detected in only 1 of 8 patients in S5 (12.5\%). There were significantly fewer tumour cells in the samples collected after MLDF processing (S5) than in the samples collected after RLDF (S4) and around the tumour (S2) ( $P=0.016$ and $P=0.039$, respectively). Although no significant difference was observed between $\mathrm{S} 4$ and $\mathrm{S} 1$, a downward trend was observed after IOCS+RLDF processing.

\section{Conclusions}

Tumour cells could be removed by IOCS combined with RLDF from blood salvaged during MSTS, but residual tumour cells remained. The findings support the notion that MLDF eliminates tumour cells more effectively than RLDF. Hence, this technique can be applied to MSTS.

\section{Trial Registration}

ChiCTR1800016162 Chinese Clinical Trial Registry http://www.chictr.org.cn/showproj.aspx?proj=27263

\section{Background}

Blood loss in spinal surgery, resulting from tumour hypervascularity, dilated epidural venous plexus, soft tissue paraspinal blood vessels, and even uninvolved bone, is still a major problem, especially in metastatic spine tumour surgery (MSTS). The average bleeding volume in MSTS has been reported as 2,180 mL [1]. Recently, Kumar et al. found that the mean bleeding volume was $870 \pm$ $720 \mathrm{~mL}$, and the average blood transfusion volume was $1.5 \pm 1.9 \mathrm{U}$ in MSTS [2]. Currently, blood loss occurring in patients undergoing major tumour surgery is mainly replenished by allogeneic blood transfusion (ABT). However, there is increasing awareness of the fact that patients undergoing tumour surgeries are more susceptible to the adverse effects of ABT, such as transfusion-related infection, tumour growth promotion secondary to immunosuppression, and other transfusion reactions (e.g., allergic reactions, acute and delayed haemolytic reactions, and graft-versus-host disease) [3]. Moreover, ABT has been found to prolong hospital stays and increase medical costs compared to intraoperative cell salvage (IOCS) [4].

Intraoperative, salvaged, autologous blood transfusions carried out with autotransfusion devices are commonly used for cardiovascular surgery. They also enable the treatment of massive haemorrhage in musculoskeletal and gynaecologic surgeries to prevent potential complications of homologous blood transfusions. However, in oncologic surgery, transfusion of salvaged blood may cause haematogenous metastasis and dissemination of malignant tumour cells. Investigators have reported that blood irradiation or filtration using a leucocyte depletion filter (LDF) can prevent contamination with malignant tumour cells. Intraoperative 
autotransfusion combined with blood irradiation or LDF could be a promising technique for the treatment of profuse haemorrhage in oncologic surgery [5]. Prospective studies have shown that IOCS alone was successful in removing tumour cells in nearly $90 \%$ of the samples and that the combination of IOCS and LDF was more effective in removing tumour cells from blood salvaged during MSTS $[6,7]$. However, this technique is still in its infancy in MSTS; thus, we conducted this study. Considering the different pathological types of spinal metastases, we found that there were still residual tumour cells present after processing by IOCS and LDF in different types of MSTS in our cases. We then improved the modified leucocyte depletion filter (MLDF) and obtained meaningful results. Currently, few studies have reported the application of combined IOCS and MLDF in MSTS. The purpose of this study was to analyse the ability of IOCS-MLDF to eliminate tumour cells and to evaluate the safety of autotransfusion based on laboratory test results in patients with MSTS.

\section{Methods}

\section{Study design and study population}

We recruited patients with metastatic spinal tumours who underwent spinal surgeries between May 2018 and May 2019 at our university hospital. The exclusion criteria were the presence of haematological or infectious diseases and not consenting to participate in the study. This study was approved by the ethics committee of Peking University Third Hospital with approval number LM2018020. The patients provided written consent. All methods were carried out in accordance with Declaration of Helsinki. Patient demographic information was recorded.

\section{Sample collection}

The suction tube and blood reservoir of the IOCS machine (Cell Saver 5+; Haemonetics Corporation, Braintree, MA, USA) were rinsed and pre-filled with $200 \mathrm{~mL}$ of anticoagulant saline (heparin saline, $30 \mathrm{IU} / \mathrm{mL}$ ). The negative pressure of the suction device was set at $120-150 \mathrm{mmHg}$. The anticoagulant drip rate was adjusted to approximately $100 \mathrm{drops} /$ minute, and the flow rate was adjusted according to the amount and speed of the recovered blood. All intraoperative shed blood was recovered from the skin incision to remove the tumour. The recovered blood was anticoagulated and washed with sterilised saline $(2,000 \mathrm{~mL}$ for $125 \mathrm{~mL}$ of red blood cells). Only salvaged blood with a haematocrit of $30-60 \%$ and volume greater than $100 \mathrm{~mL}$ was eligible for use. Two types of leucocyte reduction filters were used in this experiment: a regular leucocyte depletion filter (RLDF) and an MLDF. The RLDF had a bore diameter of $40 \mu \mathrm{m}$ (SB; Haemonetics Corporation). The MLDF had a bore diameter of $18 \mu \mathrm{m}$ (Separator Haemo-Technology Beijing Co Ltd, Beijing, China). Blood products treated with IOCS-LDF were used only for research purposes and not transfused to patients.

Blood samples were collected in 5 stages: S1, blood collected from the peripheral vein before the skin incision; S2, blood collected around the tumour during surgical manipulation; S3, IOCS blood collected after washing and before filtration using the LDF; S4, blood collected after filtration using IOCS+RLDF; and S5, blood collected after filtration using IOCS+MLDF. Twelve millilitres of blood were collected at each stage, which comprised 3 separate 4-mL samples collected at slightly different time points to avoid sampling error (Fig. 1). All blood samples were stored in ethylenediaminetetraacetic acid-coated vacutainer tubes (Becton-Dickinson, Franklin Lakes, $\mathrm{NJ}$, USA), and the tubes were stored at $4^{\circ} \mathrm{C}$. Samples were collected from 20 patients in whom RLDF was used (Group R), including 8 patients in whom MLDF was additionally used (Group M).

\section{Laboratory methods}

The polyploids of tumour cells in blood samples were collected and counted using immunomagnetic separation enrichment and fluorescence in situ hybridization (FISH). Tumour cells from blood samples were enriched using a human peripheral blood leucocyte removal kit (Cyttel ${ }^{\circledR}$, Jiangsu, China). After centrifugation of blood samples, the red blood cells were lysed and the white blood cells were removed using CD45 immunomagnetic beads. CD45 expression was detected in the remaining cells by immunofluorescence staining to further exclude the remaining leucocytes. Probes were utilized to identify centromeres of chromosomes 8 and 17 or 7 . FISH was used to determine the number of chromosomes. When the number of chromosomes 8,17 , or 7 exceeded 2 , the cell was classified as aneuploid and determined to be a tumour cell. Chromosome enumeration probe 8 (CEP 8) was utilized for the detection of samples from various cancer types [8]. At the same time, chromosome 7 (CEP 7) was counted in renal [9], colon [10], oesophageal [11], and prostate [12] cancer cells, whereas chromosome 17 (CEP 17) was counted in endometrial and breast [13] cancer cells. The results were examined and judged by 2 independent pathologists. 


\section{Statistical Analysis}

All data were analysed using SPSS 24.0 (IBM Corporation, Armonk, NY, USA.). Measurement data conforming to the normal distribution and homogeneity of variances are expressed as the mean \pm standard deviation. Non-normally distributed data are expressed as the median (interquartile range). Within-group comparisons were performed using Wilcoxon analysis. $P<0.05$ was considered statistically significant.

\section{Results}

\section{Baseline and procedural characteristics}

Between May 2018 and May 2019, 24 patients with metastatic spinal cord compression were enrolled. The IOCS-LDF device was used during surgery. Four patients were excluded because of insufficient blood samples and presence of osteosarcoma as detected on postoperative pathology. Surgical sites included the cervical vertebra (5 cases), cervicothoracic vertebra (1 case), thoracic vertebra (10 cases), and lumbar vertebra ( 4 cases). The average age of the 20 patients ( 12 men and 8 women) was $57.55 \pm 9.71$ years. The surgical duration was $138.4 \pm 47.06$ minutes. The average volumes of blood loss, red blood cell transfusion, and autologous blood recovery were $392.5 \pm 270.61,280 \pm 293.08$, and $196.25 \pm 135 \mathrm{~mL}$, respectively. (Table 1 ) 
Table 1

Patient characteristics, surgical management, and numbers of tumor cell per $4 \mathrm{ml}$ blood samples (group R)

\begin{tabular}{|c|c|c|c|c|c|c|c|c|c|c|c|c|}
\hline $\begin{array}{l}\text { Patient } \\
\text { no. }\end{array}$ & $\begin{array}{l}\text { Age / } \\
\text { years }\end{array}$ & Gender & $\begin{array}{l}\text { ASA } \\
\text { status }\end{array}$ & $\begin{array}{l}\text { Primary } \\
\text { tumor }\end{array}$ & $\begin{array}{l}\text { Location of the } \\
\text { tumor }\end{array}$ & $\begin{array}{l}\text { Blood } \\
\text { loss } \\
\text { /ml }\end{array}$ & $\begin{array}{l}\text { Blood } \\
\text { transfusion } \\
\text { / ml }\end{array}$ & $\begin{array}{l}\text { Duration } \\
\text { of } \\
\text { surgery } \\
\text { / min }\end{array}$ & $\begin{array}{l}\mathrm{S} \\
1\end{array}$ & $\begin{array}{l}S \\
2\end{array}$ & $\begin{array}{l}S \\
3\end{array}$ & $\begin{array}{l}5 \\
4\end{array}$ \\
\hline 1 & 60 & Male & II & Lung & $\begin{array}{l}\text { Cervical } \\
\text { vertebra }\end{array}$ & 200 & 0 & 102 & 0 & 0 & 3 & 1 \\
\hline 2 & 78 & Female & II & Lung & $\begin{array}{l}\text { Cervical } \\
\text { vertebra }\end{array}$ & 200 & 400 & 178 & 0 & 2 & 3 & 5 \\
\hline 3 & 56 & Male & II & Lung & $\begin{array}{l}\text { Thoracic } \\
\text { vertebra }\end{array}$ & 100 & 0 & 98 & 3 & 0 & 0 & 1 \\
\hline 4 & 60 & Male & II & Lung & $\begin{array}{l}\text { Thoracic } \\
\text { vertebra }\end{array}$ & 700 & 400 & 201 & 0 & 1 & 3 & 1 \\
\hline 5 & 63 & Female & II & Lung & $\begin{array}{l}\text { Thoracic } \\
\text { vertebra }\end{array}$ & 200 & 0 & 166 & 0 & 1 & 1 & 2 \\
\hline 6 & 66 & Male & II & Lung & $\begin{array}{l}\text { Thoracic } \\
\text { vertebra }\end{array}$ & 400 & 400 & 169 & 0 & 8 & 1 & 21 \\
\hline 7 & 53 & Female & 1 & Breast & $\begin{array}{l}\text { Cervical } \\
\text { vertebra }\end{array}$ & 150 & 0 & 74 & 2 & 1 & 0 & 0 \\
\hline 8 & 44 & Female & I & Breast & $\begin{array}{l}\text { Lumbar } \\
\text { vertebra }\end{array}$ & 600 & 0 & 124 & 2 & 2 & 1 & 0 \\
\hline 9 & 44 & Female & II & Breast & $\begin{array}{l}\text { Cervical } \\
\text { vertebra }\end{array}$ & 200 & 400 & 211 & 2 & 1 & 1 & 2 \\
\hline 10 & 62 & Male & 1 & Thyroid & $\begin{array}{l}\text { Lumbar } \\
\text { vertebra }\end{array}$ & 500 & 400 & 230 & 6 & 6 & 2 & 0 \\
\hline 11 & 59 & Female & II & Thyroid & $\begin{array}{l}\text { Thoracic } \\
\text { vertebra }\end{array}$ & 200 & 0 & 90 & 7 & 0 & 0 & 0 \\
\hline 12 & 63 & Male & II & Colon & $\begin{array}{l}\text { Lumbar } \\
\text { vertebra }\end{array}$ & 200 & 0 & 156 & 8 & 34 & 1 & 2 \\
\hline 13 & 44 & Female & II & Colon & $\begin{array}{l}\text { Thoracic } \\
\text { vertebra }\end{array}$ & 300 & 800 & 96 & 3 & 1 & 0 & 1 \\
\hline 14 & 63 & Male & II & Esophagus & $\begin{array}{l}\text { Cervical } \\
\text { vertebra }\end{array}$ & 400 & 800 & 110 & 1 & 2 & 0 & 0 \\
\hline 15 & 69 & Male & II & Esophagus & $\begin{array}{l}\text { Thoracic } \\
\text { vertebra }\end{array}$ & 200 & 400 & 87 & 3 & 2 & 1 & 1 \\
\hline 16 & 50 & Male & III & Rectum & $\begin{array}{l}\text { Thoracic } \\
\text { vertebra }\end{array}$ & 100 & 0 & 106 & 1 & 2 & 4 & 0 \\
\hline 17 & 61 & Male & II & Ampulla & $\begin{array}{l}\text { Lumbar } \\
\text { vertebra }\end{array}$ & 800 & 400 & 121 & 1 & 1 & 2 & 1 \\
\hline 18 & 42 & Female & II & Endometrium & $\begin{array}{l}\text { Cervicothoracic } \\
\text { vertebra }\end{array}$ & 600 & 0 & 137 & 3 & 1 & 0 & 0 \\
\hline 19 & 48 & Male & I & Nasopharynx & $\begin{array}{l}\text { Thoracic } \\
\text { vertebra }\end{array}$ & 1000 & 800 & 201 & 2 & 0 & 0 & 0 \\
\hline 20 & 66 & Male & II & Renal & $\begin{array}{l}\text { Thoracic } \\
\text { vertebra }\end{array}$ & 800 & 400 & 111 & 0 & 2 & 3 & 2 \\
\hline
\end{tabular}




\section{Primary Tumour Origin}

The origin of the primary lesions was mainly in the lungs ( 6 cases), gastrointestinal tract ( 6 cases, including 2 in the colon, 2 in the oesophagus, 1 in the rectum, and 1 in the ampulla), breasts (3 cases), thyroid ( 2 cases), endometrium (1 case), nasopharynx ( 1 case), and kidneys (1 case) (Table 1), which were confirmed by pathological evaluation of paraffin sections stained with haematoxylin-eosin and by immunohistochemistry (Fig. 2).

\section{Detection Of Tumour Cells}

Overall, 88 samples from 20 patients (including 20 samples each for S1, S2, S3, and S4 and 8 samples for S5) were analysed. After excluding CD45+ leucocytes using immunomagnetic beads (Fig. 3), aneuploidy (abnormal chromosome numbers) was detected in CEP 8, CEP 17, or CEP 7 by FISH. Tumour cells were recognized and counted using immunofluorescence staining and FISH. Negative expression of CD45 and aneuploidy of CEP 8, CEP 17, and CEP 7 were considered to indicate malignant cells (Fig. 3).

\section{Ability Of Mldf And RIdf To Eliminate Tumour Cells}

The number of tumour cells in all of the samples is shown in Tables 1, Tables 2 and Fig. 4. Tumour cells were detected in S1 in 14 patients (70\%), S2 in 16 patients (80\%), S3 in 13 patients (65\%), and S4 in 12 patients (60\%) (Table 1 and Fig. 4A). In 8 patients, MLDF was used, and tumour cells were detected in only 1 patient (12.5\%) in S5 (Table 2 and Fig. 4B). There was no significant difference between S4 and S1 $(P=0.165)$ or between S4 and S2 $(P=0.426)$, although a downward trend appeared after IOCS+RLDF processing. The number of tumour cells was significantly lower in the $\mathrm{S} 5$ samples after

Table 2

Patient characteristics, surgical management, and numbers of tumor cell per $4 \mathrm{ml}$ blood samples (group M)

\begin{tabular}{|c|c|c|c|c|c|c|c|c|c|c|c|c|c|}
\hline $\begin{array}{l}\text { Patient } \\
\text { no. }\end{array}$ & $\begin{array}{l}\text { Age / } \\
\text { years }\end{array}$ & Gender & $\begin{array}{l}\text { ASA } \\
\text { status }\end{array}$ & $\begin{array}{l}\text { Primary } \\
\text { tumor }\end{array}$ & $\begin{array}{l}\text { Location } \\
\text { of the } \\
\text { tumor }\end{array}$ & $\begin{array}{l}\text { Blood } \\
\text { loss } \\
\text { /ml }\end{array}$ & $\begin{array}{l}\text { Blood } \\
\text { transfusion } \\
/ \mathrm{ml}\end{array}$ & $\begin{array}{l}\text { Duration } \\
\text { of surgery } \\
\text { / min }\end{array}$ & $\begin{array}{l}S \\
1\end{array}$ & $\begin{array}{l}S \\
2\end{array}$ & $\begin{array}{l}S \\
3\end{array}$ & $\begin{array}{l}S \\
4\end{array}$ & $\begin{array}{l}S \\
5\end{array}$ \\
\hline 1 & 48 & Male & I & Nasopharynx & $\begin{array}{l}\text { Thoracic } \\
\text { vertebra }\end{array}$ & 1000 & 800 & 201 & 2 & 0 & 0 & 0 & 0 \\
\hline 2 & 66 & Male & ॥ & Renal & $\begin{array}{l}\text { Thoracic } \\
\text { vertebra }\end{array}$ & 800 & 400 & 111 & 0 & 2 & 3 & 2 & 0 \\
\hline 3 & 56 & Male & ॥ & Lung & $\begin{array}{l}\text { Thoracic } \\
\text { vertebra }\end{array}$ & 100 & 0 & 98 & 3 & 0 & 0 & 1 & 0 \\
\hline 4 & 61 & Male & ॥ & Ampulla & $\begin{array}{l}\text { Lumbar } \\
\text { vertebra }\end{array}$ & 800 & 400 & 121 & 1 & 1 & 2 & 1 & 0 \\
\hline 5 & 60 & Male & ॥ & Lung & $\begin{array}{l}\text { Thoracic } \\
\text { vertebra }\end{array}$ & 700 & 400 & 201 & 0 & 1 & 3 & 1 & 0 \\
\hline 6 & 63 & Female & ॥ & Lung & $\begin{array}{l}\text { Thoracic } \\
\text { vertebra }\end{array}$ & 200 & 0 & 166 & 0 & 1 & 1 & 2 & 1 \\
\hline 7 & 44 & Female & ॥ & Breast & $\begin{array}{l}\text { Cervical } \\
\text { vertebra }\end{array}$ & 200 & 400 & 211 & 2 & 1 & 1 & 2 & 0 \\
\hline 8 & 66 & Male & ॥ & Lung & $\begin{array}{l}\text { Thoracic } \\
\text { vertebra }\end{array}$ & 400 & 400 & 169 & 0 & 8 & 1 & 21 & 0 \\
\hline
\end{tabular}

S1: number of CTCs / 4ml in S1;S2: number of CTCs / $4 \mathrm{ml}$ in S2; S3: number of CTCs / $4 \mathrm{ml}$ in S3; S4: number of CTCs / $4 \mathrm{ml}$ in S4; S5: number of CTCs / 4ml in S5.

\section{Discussion}

Blood loss during MSTS remains challenging, although minimally invasive surgical techniques have greatly improved. Blood loss varies greatly depending on the primary tumour of spinal metastases, surgical approaches, and operative time [2]. The average volume of blood loss has been reported as $1,418 \mathrm{~mL}(713.3-3,120 \mathrm{~mL})$ in open and conventional spine surgery for vertebral 
metastases and $745 \mathrm{~mL}(184-1,320 \mathrm{~mL})$ in minimally invasive spinal metastatic tumour surgery [14]. In the present study, the average volume of blood loss was $392.5 \pm 270.61 \mathrm{~mL}$, which is less than that reported in other studies. Eleven patients received ABT with an average transfusion volume of $280 \pm 293.08 \mathrm{~mL}$. The prevalence of anaemia in patients with cancer is reported to be approximately $40 \%$ [15] due to nutritional deficiency, chronic disease, blunted response to erythropoietin, bone marrow suppression either due to cancerous cells or as a side effect of chemotherapy/radiotherapy, and other causes [16]. Transfusion requirements are usually larger than expected. Thus, the investigation of IOCS+LDF is valuable for patients.

There is still controversy around the clinical safety of using salvage blood in oncological surgeries, despite literature establishing its safety. LDF is a filter device based on a membrane-like filter material used to remove leucocytes from the blood. The mechanisms underlying the removal of tumour cells are physical interception and charge adsorption based on cell size. The size of white blood cells is approximately 7-20 $\mu \mathrm{m}$. The RLDF refers to a white blood cell filter with a pore size of $40 \mu \mathrm{m}$. Gray et al. conducted a prospective cohort study and found no significant difference in progression-free survival between preoperative autologous donation and IOCS-LDF groups undergoing prostatectomy [17]. Patients who undergo partial hepatectomy for colorectal cancer metastases can safely receive a transfusion of filtered autologous blood, which is not associated with an increased risk of recurrence or a higher mortality rate [18]. Patients who received a salvaged blood transfusion required significantly lesser amounts of allogeneic blood, and their survival rates and disease progression remained lower or similar to that in control patients. Furthermore, there are many studies on the clinical safety of salvage blood used in oncological surgeries, including gynaecological [19], hepatobiliary [20, 21], gastrointestinal [22], urological [17], and pulmonary [23] surgery. However, there are only a few studies on IOCS+LDF reinfusion in patients with MSTS. Gakhar et al. observed that transfusion of intraoperatively salvaged blood did not result in disseminated metastatic cancer in MSTS (level of evidence IV) [24].

In this study with 20 patients, tumour cells were detected in the blood samples of 12 patients (60\%) after IOCS+RLDF processing (S4), whereas it was found in venous blood before surgery (S1) in 14 (70\%), in blood from the operative field (S2) in 16 (80\%), and in blood after IOCS (S3) in 13 patients (65\%). There was no significant difference between S4 and S1 or between S4 and S2, although a downward trend appeared after IOCS+RLDF processing (Fig. 4). This may imply that RLDF could not completely eliminate tumour cells. With the aim to discover more effective methods, Mei et al. reported a 3-4 log reduction in leucocytes using MLDF with a pore size of 12-18 $\mu \mathrm{m}$ [25]. RLDF-treated samples were subsequently inoculated in nude mice, $67 \%$ of which developed tumours. In contrast, no tumour cells were found in MLDF-treated samples, and no solid tumours were observed in inoculated nude mice [25]. Therefore, it is considered that MLDF with mannitol-adenine-phosphate solution had higher filter efficiency, but further clinical research is warranted. Thus, we explored MLDF with a pore size of $18 \mu \mathrm{m}$ to filter spinal metastasis tumour cells from known primary epithelial tumours. The number of tumour cells was significantly lower in the samples after MLDF processing (S5) than in the operative field (S2). We also confirmed that MLDF was more effective in eliminating tumour cells and safer than RLDF. In this study, MLDF was more efficient for filtering tumour cells, which suggests that it may have great prospects for managing blood salvage in oncologic surgery.

Ideally, we try to eliminate all tumour cells from salvaged blood. In our study, IOCS+RLDF markedly reduced the number of tumour cells in patients' peripheral venous blood, but it did not eliminate them completely. However, MLDF achieved a clearance rate of zero. Karczewski et al. demonstrated that $62 \%$ of the tumour cells in blood underwent lethal trauma, whereas all the remaining tumour cells displayed morphological changes, after being processed with the IOCS device [26]. Kumar et al. reported that the tumour cells that pass through the IOCS device are morphologically altered and become nonviable and that they lose their ability to form new metastatic deposits [27]. Similar results were observed in other studies $[7,19]$. Therefore, we assume that IOCS+MLDF would be an effective strategy to destroy and eliminate malignant cells and that salvaged autologous blood can be safely reinfused to the patient.

\section{Strength and limitations of this study}

- MLDF was applied for the first time on patients of MSTS in China.

- The salvaged blood used in this study was not reinfused to patients because of the limitations imposed by ethical issues.

- We failed to clarify the viability and functionality of the tumour cells because there were too few residual tumour cells to evaluate.

\section{Conclusions}


This study evaluated the effectiveness of IOCS combined with MLDF in MSTS. Although tumour cells could be removed by IOCS combined with RLDF from blood salvaged during MSTS, there were still residual tumour cells remaining. These findings support the notion that MLDF eliminates tumour cells more effectively than RLDF. Hence, this technique can be applied in MSTS.

\section{List Of Abbreviations}

IOCS: intraoperative cell salvage, MLDF: modified leucocyte depletion filter, RLDF: regular leucocyte depletion filter, MSTS: metastatic spine tumour surgery, ABT: allogeneic blood transfusion, LDF: leucocyte depletion filter, FISH: fluorescence in situ hybridization, CEP: Chromosome enumeration probe, HE: haematoxylin-eosin, FISH: fluorescence in situ hybridisation.

\section{Declarations}

Ethics approval and consent to participate: The study was approved by Peking university third hospital medical ethics committee (No. LM2018020) and each participant provided written informed consent.

Consent for publication: Not Applicable.

Availability of data and materials: The data during this study are available from the corresponding author on reasonable request.

Competing interests: The authors declare that they have no competing interests.

Funding: The present study was supported by Key Clinical Projects of Peking University Third Hospital (No. BYSY2017001).

Authors' contributions: $\mathrm{YYZ}$ and $\mathrm{CX}$ designed and coordinated the study, recruited the patients, collected and interpreted data, and drafted the manuscript. YG and XZ analyzed the data and performed statistical analysis, $C L$ and $B Z$ participated in patient recruitment and data collection, $\mathrm{LX}$ and $\mathrm{HZ}$ participated in study design. XG, FW and YL contributed to the conception of the study. All authors discussed the results, read and approved the final manuscript.

Acknowledgments: We sincerely thank all the staff of the Anesthesiology Department of Peking university third hospital for their help in this research.

\section{References}

1. Chen Y, Tai BC, Nayak D, Kumar N, Lim JW, Goy RWL, et al. Blood loss in spinal tumour surgery and surgery for metastatic spinal disease: a meta-analysis. Bone Joint J 2013; 95-B:683-8.

2. Kumar N, Zaw AS, Khine HE, Maharajan K, Wai KL, Tan B, et al. Blood Loss and Transfusion Requirements in Metastatic Spinal Tumor Surgery: Evaluation of Influencing Factors. Ann Surg Oncol 2016; 23:2079-86.

3. Zaw AS, Kantharajanna SB, Maharajan K, Tan B, Vellayappan B, Kumar N. Perioperative blood transfusion: does it influence survival and cancer progression in metastatic spine tumor surgery? Transfusion 2017; 57(2):440-50.

4. Elmalky M, Yasin N, Rodrigues-Pinto R, Stephenson J, Carroll C, Smurthwaite G, et al. The safety, efficacy, and cost-effectiveness of intraoperative cell salvage in metastatic spine tumor surgery. Spine J 2017; 17(7):977-82.

5. Kumar N, Chen Y, Zaw AS, Nayak D, Ahmed Q, Soong R, et al. Use of intraoperative cell-salvage for autologous blood transfusions in metastatic spine tumour surgery: a systematic review. Lancet Oncol 2014; 15(1): e33-41.

6. Kumar N, Ahmed Q, Lee VK, Chen Y, Zaw AS, Goy R, et al. Can there be a place for intraoperative salvaged blood in spine tumor surgery? Ann Surg Oncol 2014; 21:2436-43.

7. Kumar N, Ahmed Q, Lee VK, Zaw AS, Goy R, Wong HK. Are we ready for the use of intraoperative salvaged blood in metastatic spine tumour surgery? Eur Spine J 2016; 25:3997-4007.

8. Lin PP. Integrated EpCAM-independent subtraction enrichment and iFISH strategies to detect and classify disseminated and circulating tumors cells. Clin Transl Med 2015; 4:38.

9. Brunelli M, Eble JN, Zhang S, Martignoni G, Cheng L. Gains of chromosomes 7, 17, 12, 16, and 20 and loss of Y occur early in the evolution of papillary renal cell neoplasia: a fluorescent in situ hybridization study. Mod Pathol 2013; 16:1053-9. 
10. Sayagues JM, Abad Mdel M, Melchor HB, Gutierrez ML, Gonzalez-Gonzalez M, Jensen E, et al. Intratumoural cytogenetic heterogeneity of sporadic colorectal carcinomas suggests several pathways to liver metastasis. J Pathol 2010; 221:308-19.

11. Hao JJ, Yao HQ, Dai GY, Kang W, Jia XM, Xu X, et al. Chromosomal aneuploidies and combinational fluorescence in situ hybridization probe panels are useful for predicting prognosis for esophageal squamous cell carcinoma. J Gastroenterol 2015; 50:155-66.

12. Konig JJ, Teubel W, Romijn JC, Schroder FH, Hagemeijer A. Gain and loss of chromosomes 1, 7, 8, 10, 18, and Y in 46 prostate cancers. Hum Pathol 1996; 27:720-7.

13. Tse $\mathrm{CH}$, Hwang HC, Goldstein LC, Kandalaft PL, Wiley JC, Kussick SJ, et al. Determining true HER2 gene status in breast cancers with polysomy by using alternative chromosome 17 reference genes: implications for anti-HER2 targeted therapy. J Clin Oncol 2011; 29:4168-74.

14. Pennington Z, Ahmed AK, Molina CA, Ehresman J, Laufer I, Sciubba DM. Minimally invasive versus conventional spine surgery for vertebral metastases: a systematic review of the evidence. Ann Transl Med 2018; 6:103.

15. Ludwig H, Van Belle S, Barrett-Lee P, Birgegard G, Bokemeyer C, Gascon P, et al. The European Cancer Anaemia Survey (ECAS): a large, multinational, prospective survey defining the prevalence, incidence, and treatment of anaemia in cancer patients. Eur $\mathrm{J}$ Cancer 2004; 40:2293-306.

16. Schrijvers D. Management of anemia in cancer patients: transfusions. Oncologist 2011; 16 Suppl 3:12-8.

17. Gray CL, Amling CL, Polston GR, Powell CR, Kane CJ. Intraoperative cell salvage in radical retropubic prostatectomy. Urology $2001 ; 58: 740-5$.

18. Kang R, Seath BE, Huang V, Barth RJ, Jr. Impact of Autologous Blood Transfusion on Survival and Recurrence among Patients Undergoing Partial Hepatectomy for Colorectal Cancer Liver Metastases. J Am COLL surg 2019; 228:902-8.

19. Catling S, Williams S, Freites $O$, Rees M, Davies C, Hopkins L. Use of a leucocyte filter to remove tumour cells from intra-operative cell salvage blood. Anaesthesia 2008; 63:1332-8.

20. Foltys D, Zimmermann T, Heise M, Kaths M, Lautem A, Wisser G, et al. Liver transplantation for hepatocellular carcinoma-is there a risk of recurrence caused by intraoperative blood salvage autotransfusion? Eur Surg Res 2011; 47(3):182-7.

21. Liang TB, Li DL, Liang L, Li JJ, Bai XL, Yu W, et al. Intraoperative blood salvage during liver transplantation in patients with hepatocellular carcinoma: efficiency of leukocyte depletion filters in the removal of tumor cells. Transplantation 2008; 85(6):8639.

22. Bower MR, Ellis SF, Scoggins CR, McMasters KM, Martin RC. Phase Il comparison study of intraoperative autotransfusion for major oncologic procedures. Ann Surg Oncol 2011; 18(1):166-73.

23. Perseghin P, Vigano M, Rocco G, Della Pona C, Buscemi A, Rizzi A. Effectiveness of leukocyte filters in reducing tumor cell contamination after intraoperative blood salvage in lung cancer patients. Vox Sang 1997; 72(4):221-4.

24. Gakhar H, Bagouri M, Bommireddy R, Klezl Z. Role of intraoperative red cell salvage and autologus transfusion in metastatic spine surgery: a pilot study and review of literature. Asian Spine J 2013; 7:167-172.

25. Mei K, Du L, Yan M, Zhang Z, Zhang F, Gong L, et al. Modified Leukocyte Filter Removes Tumor Cells from the Salvaged Blood. PLoS One 2015; 10: e0130864.

26. Karczewski DM, Lema MJ, Glaves D. The efficiency of an autotransfusion system for tumor cell removal from blood salvaged during cancer surgery. Anesth Analg 1994; 78:1131-1135.

27. Kumar N, Zaw AS, Khoo BL, Nandi S, Lai Z, Singh G, et al. Intraoperative cell salvage in metastatic spine tumour surgery reduces potential for reinfusion of viable cancer cells. Eur Spine J 2016, 25:4008-4015.

\section{Figures}



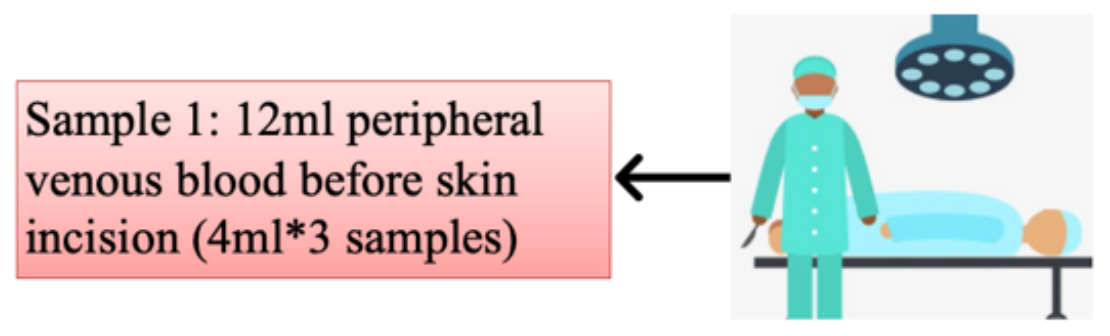

Sample 3: $12 \mathrm{ml}$ salvaged blood after IOCS $(4 \mathrm{ml} * 3$ samples)

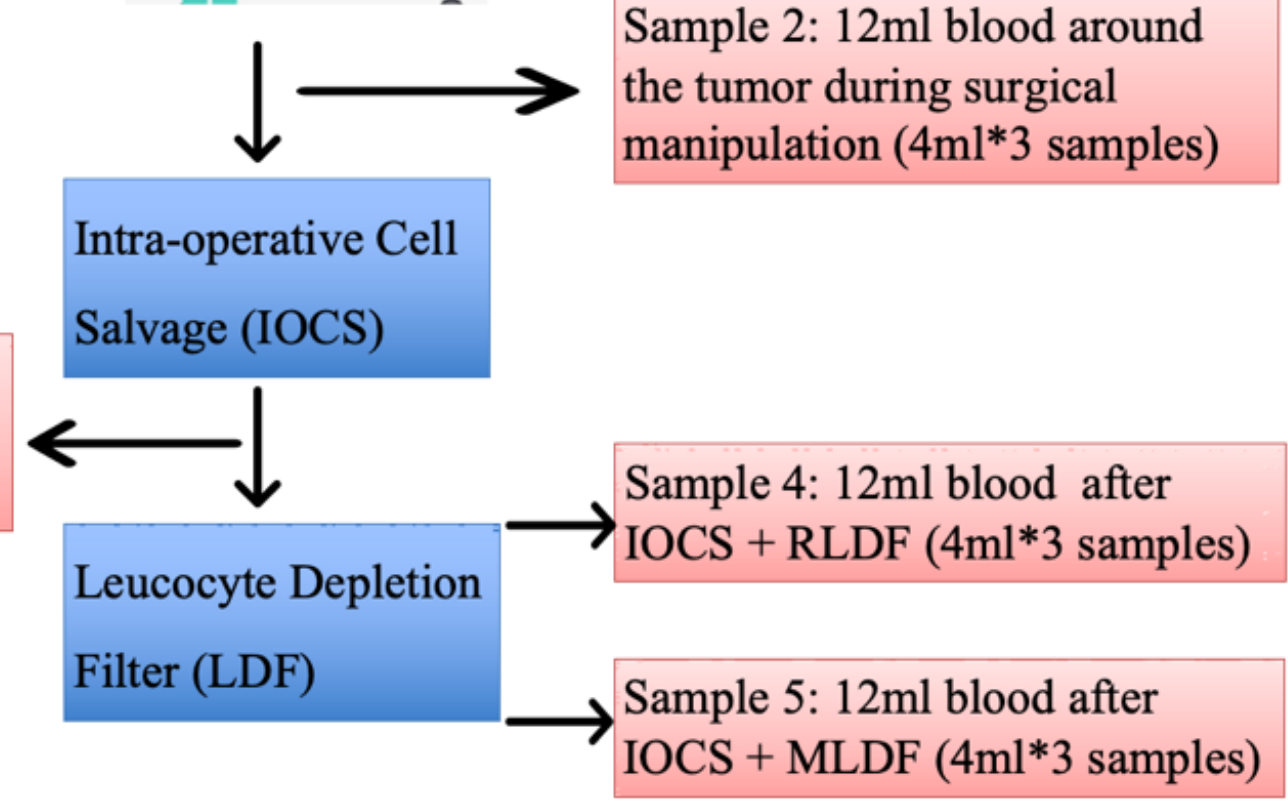

Figure 1

Stages of blood samples collection during surgery

There are 5 stages for blood sample collection. S1, peripheral venous blood from peripheral vein before skin incision; S2, blood sampled around the tumor during surgical manipulation; S3, IOCS blood after washing and before LDF filtering; S4, blood sample after IOCS+RLDF filtration; and S5, blood sample after IOCS+MLDF filtration. $15 \mathrm{ml}$ blood sample was collected which comprised three separate $5 \mathrm{ml}$ sample taken at slightly different time points to avoid sampling error

Figure 2

The pathology images of MSTS.

(A) Bone metastasis of breast cancer stained with hematoxylin-eosin staining (HE); (B) Bone metastasis of breast cancer stained with GATA3; (C) Bone metastasis of colon cancer stained with HE; (D) Bone metastasis of colon cancer stained with CK20. Scale bar $=50$ $\mu \mathrm{m}$

\section{Figure 3}

Detection of tumor cells. 
The expression level of CD 45 and the number of chromosome, such as CEP 8, CEP 17 or CEP 7 could be distinguished by immunofluorescence staining and FISH. The cells with negative CD45 expression and one or all of CEP 8, CEP 17 or CEP 7 abnormal number (number $\geq 3$ ) were identified as circulating tumor cells. The positive expression of CD 45 were discriminated as WBC. CEP 8 is the centromere signal of chromosome 8, CEP 7 is the centromere signal of chromosome 7, CEP 17 is the centromere signal of chromosome 17. Scale bar: $5 \mu \mathrm{m}$

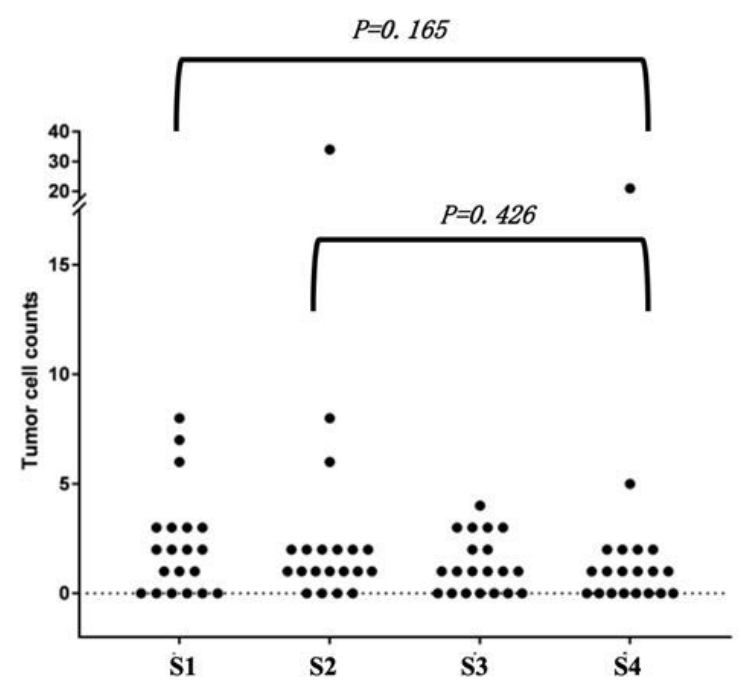

Fig. $4 \mathrm{~A}$

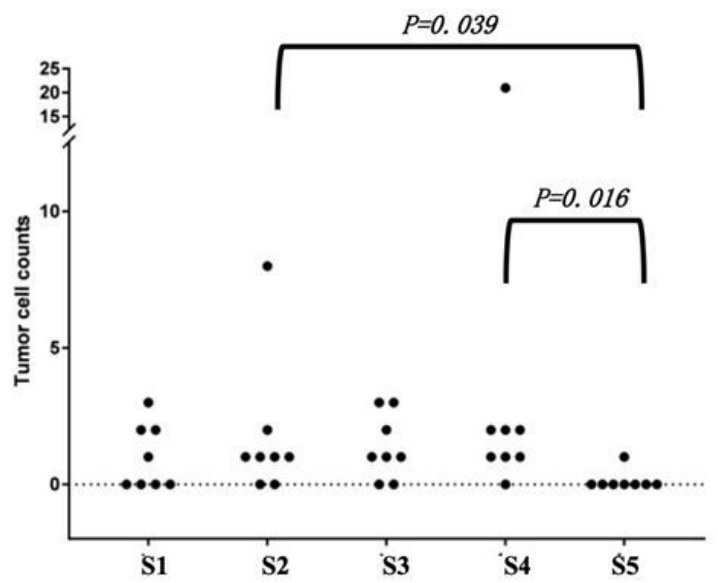

Fig. 4 B

\section{Figure 4}

All of tumor cell counts in each sample $(4 \mathrm{ml})$.

(A) Tumor cell counts in 20 cases processed by RLDF; (B) Tumor cell counts in 8 cases processed by RLDF and MLDF 